\title{
BURIED WITHIN SITES AND SEDIMENTS: THE RELATIONSHIP OF MEMORY AND PLACE IN GEORGES PEREC'S W OR THE MEMORY OF CHILDHOOD AND ANNE MICHAELS'S FUGITIVE PIECES
}

\author{
Hogar NAJM ABdullah \\ Dept. of English, College of Languages, University of Duhok, Kurdistan Region-Iraq
}

(Received: September 21, 2020; Accepted for Publication: April 4, 2021)

\begin{abstract}
ABSRACT
This paper illustrates the ways Georges Perec's W or the Memory of Childhood and Anne Michaels's Fugitive Pieces unravel the implicit links between place and memory. As Perec portrays the biography of a character whose childhood memories are distorted by the catastrophe of Holocaust, Michaels; on the other hand, depicts the experience of the lack of memory of the survivors of Holocaust extended to the next generations. In their narratives, both writers attempt to unfold the essence of the unfolding relationship between memory and place and the ways it contributes to the main characters' pasts, and thus, to their identities. By relying on a number of theoretical frames related to memory studies such as Nicola King (2000) and Simon Schama (1996), the paper argues that the protagonists of the selected novels come to a better understanding of themselves, relying on several places and sites in reconstructing their memories. This research investigates the relationship between memory and place to elaborate on the key roles of the place in conceiving and revealing the buried memories in the two novels.
\end{abstract}

KEYWORDS: Anne Michaels, Georges Perec, Holocaust Literature, Memory Studies, Post-modern Fiction

\section{INTRODUCTION}

B oth Georges Perec's W or The Memory of Childhood and Anne Michaels's Fugitive Pieces deliberate the possible ways memories are conceived by the survivors and the next generation victims of Holocaust. They can be read as an attempt to fill in the gaps of survivors' memories and the memories of those who experienced this tragic catastrophe and were destroyed by it. At the beginning of his autobiographical novel, Perec chooses a startling statement expressing his lack of memory: "I have no childhood memories" (Perec, 2011:1). To compensate for his inaccessible past, Perec builds up a relationship between his imagination and space. This relationship is strengthened by originating the fantasy of the island of $\mathrm{W}$ and revisiting various places, which in one way or another are related to different stages of his life.

On a similar level, Michaels negotiates the inevitability of the void in the life of her novel's protagonist, Jacob Beer. Jacob makes it clear from the opening pages of the novel that he is haunted by a sense of failure to have comprehensible memories about the most crucial events of his life for not witnessing them: "I did not witness the most important events of my life" (Michaels, 1998:3). Through the influence of Athos Roussos, the person who rescues him from death, and his own longing to space, Jacob is seen to appreciate the earth and scrutinize it in the hope of finding out traces of his past. "What we save, save us" and "What is a man who has no landscape?" are some of the values that Jacob learns from Athos regarding place. Furthermore, Michaels uses different sites of memories, such as sediments or the ruins of certain places, to elaborate on the idea of biological and archaeological conception of memory.

\section{HOUSES, RUINS AND EPITAPHS AS CONCRETE SITES OF MEMORIES}

$W$ or The Memory of Childhood was originally published in French in 1975 and translated into English in 2011 by David Bellos. Being a Holocaust narrative and picturing an imaginary island, the novel is an ideal trauma text. It is an outcome of Perec's extreme childhood life represented in his depiction of a fictionalised self-discovery journey. The 
protagonist's actual journey starts the moment he is asked to take a voyage to South American Islands in search of the body of Gaspard Winckler whose name is given to Perec. The boy is deaf and dumb and is taken by his mother in a long healing sea-voyage. Consequently, their ship is wrecked, and all dead bodies are found except the child's. Finding out a lost and a traumatised child is the essence of Perec's book which breaks off, shortly, into elaborations on the island of $\mathrm{W}$. The island is located in a region which is dedicated to the 'Olympian ideal' in every respect and its roles are based on aggressive kinds of sport. The society of $\mathrm{W}$ is described, at the start, as being cool and happy countryside. Then, Perec represents $\mathrm{W}$ as a "nation of athletes where sport and life unite in a single magnificent effort" (Perec, 2011:67).

Perec draws the Nazis' Concentration Camps as a number of hints can be observed about $\mathrm{W}$ as indicators for that such as the fact that the life in $\mathrm{W}$ is lived for the greater glory of the body. The brutal primitive reality of $\mathrm{W}$ is in struggling for survival: the survival for the fittest. The survival under illogical laws and raping women in mass numbers by the victors from the athletes is a reference to another phase of the death camps. To fail in $\mathrm{W}$ means to have no opportunities of winning a further contest; it means to be a subject of all sorts of humiliations. Some losers are even stoned to death. The boys born in $\mathrm{W}$ are reared within their mothers' districts up to the age of fourteen, which is near to Perec's age while inventing the story of $\mathrm{W}$. They then start to take part in some violent athletic rituals in which they end up collapsed down the ground. After that, they are seen to tear each other for a piece of salami or a drop of water. As Nicola King states: "little by little, the island of W takes the shape of the concentration camps" from Perec's descriptions. (King, 2000:129)

Auschwitz is known as the post-war symbol of Holocaust that represents concentration camps or the death camps. It has remained an emblem of Nazi terror, fascist aggression and oppression in the minds of Jewish people since the end of WWII. Auschwitz, as Andrew Charlesworth (1995:580) notes, is a term predates the widespread use of the term Holocaust at least by fifteen years. Auschwitz as a site of exterminating Jewish people is portrayed metaphorically by Perec as the island of $\mathrm{W}$. He creates this island mainly to tell his story and have some sort of means to his past. $\mathrm{W}$ as a place provide possible traces to Perec's memories and make them more approachable, as reconstructed in a text of narrative. Additionally, Perec himself reveals his perspective behind the invention of $\mathrm{W}$ :

When I was thirteen I made up a story which I told and drew in pictures. Later I forgot it. Seven years ago, one evening, in Venice, I suddenly remembered that the story was called $\mathrm{W}$ and it was, in a way, if not the story of my childhood, then at least a story of my childhood. (Perec, 2011:6)

Based on this, $\mathrm{W}$ is essential for drawing the necessary lines to understand Perec's story as he makes it clear that the writing of $\mathrm{W}$ carries the meaning of his past life. The change of the article from the 'the' to 'a' before the term 'story' is significant here. If $\mathrm{W}$ is not a representation of death camps, which is Perec's major purpose behind the story, it must be then a story that exposes some other stages of his life. If it is not the death place of his mother who is victimised in Nazi camps and a memory that haunts Perec throughout the book, it is; then, some other places which define Perec's childhood story.

Space is one of the emerging themes marking Perec's literary career. The French author seems to be preoccupied with a question regarding space that he cited from the French playwright Jean Tordien hi his essay 'Species of Spaces' in 1974: 'Granted there is a wall, what's going behind it?' Applying this quotation to Perec's $W$ or The Memory of Childhood, Perec appears to strip away from the outer side of all places he delineates and concerns himself about what lies behind the borders of the seen only. By his illustrations of the island of $\mathrm{W}$, Perec attempts to fight an 'aggressive battle' with space, trying to utilise, understand and own it. By understanding $\mathrm{W}$ in terms of space, he can draw a graspable picture of Auschwitz. He can, ultimately, imagine answers for his unfinished and haunting questions about his mother's destiny. (Pantos, 1998)

Alan Astro (1987: 869) enhances the allegorical readings of Perec's novel in his article 'Allegory in Georges Perec's W ou le souvenir d'enfance'. Despite stating that the fictional world of $\mathrm{W}$ stands for the concentration camps of Auschwitz, he suggests that it can be read as the many places Perec lives in after his departure from his family. This means that Perec's descriptions of the sport camps can be deciphered as shaping the disruptions in him as a child who is sent from Paris to many places after the death of his father and the deportation of his 
mother to the death camps. "I lost my father at four, my mother at six; I spent the war in various boarding houses at Villard-de-Lans. In 1945, my father's sister and her husband adopted me." (Perec, 2011:6) W refers to a sense of dislocation or a sense of dwelling various places in which Perec does not belong to them. He feels displaced in inhabiting places which belong to other. After being adopted by his paternal aunt, he goes to live with his maternal aunt, Esther, in Rue Vilin in 1946, and then, he is sent to Le Clos-Margot, a children's home. The actual time of Perec's joining this home is not stated, but it is from his early childhood period. After the era of the Liberation of France, he spends a few months with his grandmother. His state of not being settled in a specific place causes a feeling of alienation for Perec and makes him feel unsafe, as if being sent from one place to another means that he is rejected by the place itself. This could be a reason that might have led Perec to invent a world in which he drives its roles and inconsistencies from his real world.

Lack of epitaphs is a focal point in Perec's life. A direct connection can be established between the act of inventing $\mathrm{W}$ and Perec's failure in realizing the burial place of his mother. Hence, for Perec, creating an imaginary place in writing is a substitute for his mother's grave; it is an invisible tombstone dedicated to the memory of the unburied dead body of his mother. As it is evident in the following excerpt:

My mother had no grave. It was only 13 October 1958 that she was officially declared to have died on 11 February 1943 at Drancy (France). A subsequent decree dated 17 November 1959 stipulated that had she been of French nationality she would have been entitled to the citation Died for France. (Perec, 2011:41)

Perec knows about his mother's death only from the official certificate he receives in 1958 which declares her death. His mother being a Polish refugee in France and never given French citizenship, is not even awarded the honour of holding the title 'Died for France'. As a reaction to his mother's sorrowful and offensive end, Perec translates her memory in terms of place which serves as a site of mourning and illustrates the lingering memory of his mother. By this, Perec creates a grave for his mother in writing; he makes the text of his novel a tomb honouring and immortalising the memory of his mother.

Perec's memory of the parachute which takes place at a train station in Gare de Lyon with his mother serves as the last encounter between his mother and himself. It indicates a permanent separation between the two as well. In the autobiographical sections of $W$ or The Memory of Childhood, Perec gives several versions of this departure and is seen to be haunted by its memory. It is worth mentioning that this scene of the final meeting of the mother is not known when it happens. This enduring memory occurs in two spatial markers which are: the parachute, a horizontal marker; Perec's falling from the sky to the earth, and the train, a vertical marker; Perec's travelling from Paris to Grenoble. The horizontal marker evokes the memory of falling, suspension and departure to Perec's mind, and these three elements associated with the horizontal marker stand for different visions related to his parting from his mother. The vertical one entails to juxtapose two images together. It works as a conjunction between life and death. Perec is not aware that he is boarding a train that will lead him to a free life in Paris and, at the same time, his mother is to board another train leading her to Auschwitz and death. Falling and departure are warning markers that point to space that moves back and forth between life and death. In other words, both the train and the parachute inhabit a liminal space that marks an area between the free life of Perec and his mother's death in concentration camps. (Kaufman, 1998:46)

As being possessed by the traumatic memory of his mother's leave-taking, Perec himself strengthens his relationship with the space in vertical terms. Towards the end of the novel, while he talks about his travelling to Paris with his aunt, Berthe, and her son, Henry, Henry teaches him "to count the kilometers by observing the outside edge of the right-hand track". Consequently, he carries on considering the distance to any place he travels to for the rest of his life. "It is a habit I've kept." (Perec, 2011:156-57)

Landscapes and buildings are shown as a "condensed world" in Pallasma's (2009:19) words, in which they construct people's understanding of the world. Moreover, buildings are described in terms of their importance in recovering 'cultural human narratives'. For instance, one can remember their childhood life through the houses and places he is reared in. In an attempt to recapture his childhood memories, Perec revisits some of the places where he lived at as a child. Perec refers to the significance of the place as he talks about 'the absence of landmarks' to save his memories, there is 
"Nothing to anchor them or hold them down" (Perec 2011:68). This certifies Perec's awareness of the point that a tangible site is required for memories to be kept in. Due to the same absence of place markers, he fails in recalling many aspects of his childhood life. This failure is due to his inability to recognise some places he returns to because they 'had no name'. In 1970, he revisits a house he lived in with his aunt, Esther. As he makes it clear at the process of writing this book, he does not have any precise memory about the house even that it is not a long time that he passed by the house. Being motivated to find more about his past, he visits 'Collége Tureme', a religious school he attended as a nearly nine-year old boy.

Considering Perec's returning to the buildings he spends his childhood in, it can be argued that he believes, as Pierre Nora argues, that memory takes place in concrete elements like place, for instance. For the memory to be defined, it needs to be attached to such element. Furthermore, Nora's conception of the relationship between memory and space is more obvious in his notion of 'sites of memory' or 'lieux de memoire' in his essay, "Between Memory and History". $\mathrm{He}$ refers to a number of sites like burial places, cathedrals and some other places which embody material traces to the past. As it has been mentioned, this point seems to be applicable to Perec's continuous revisiting to different places (Nora, 1989:22).

Towards the end of $W$ or The Memory of Childhood, Perec mentions another incident from his childhood related to an exhibition about concentration camps, Perec (2011: 157) writes

Later on, my aunt took me to see an exhibition about concentration camps. It was being held near La Motte-Picquet-Grenelle (that same day, I learnt there were metro stations that were not underground but on stilts). I remember the photographs of the walls of the gas chambers showing scratch marks made by the victims' fingernails, and a set of chessmen made from bits of bread.

This shows his aunt's consciousness of Perec's need for a site to mourn over his mother's unknown decease in the death camps and his need to reconcile with her lasting memory. At the same time, visiting this memorial is of importance for Perec to find solid paths to the events of his traumatic past and to overcome them. However, as there is something artificial about the sites of memory, Perec senses this artificiality in the museum. He seems to be very disappointed in describing it, as the complete horror and the devastating meaning of the experience of Holocaust and the death camps are not fully registered in what is being exhibited. That is to say, he is consistent that what he feels will never be represented in any site of memory or that any site if memory can never convey the real experience and the real meanings of the past events.

\section{DIGGING AND UNCOVERING BURIED MEMORIES IN SEDIMENTS}

Michaels's Fugitive Pieces is regarded one of the significant literary Holocaust texts in terms of its dealing with place. The author's obsessions with topography and growing interests in geology are what make the book a distinctive narrative of a Holocaust survivor. The first part of the novel is about Jacob Beer, a Polish Jew whose parents are murdered by the German Nazis when he is only five years old. He stays alive only because he hides himself behind the wallpaper in the cupboard of his parents' house. While hiding, he witnesses how brutally his parents are killed but cannot see what happens to his beloved sister, Bella, who is most probably abducted by the Nazis. Then, he runs away from the house towards the forest and buries himself in the mud so as not to be found by the Nazis. Therefore, Jacob's relationship starts with earth from his early childhood as his only chance of survival is in digging his own grave. Athos Roussos, a Greek archeologist who digs in the area where Jacob's family lives, Biskupin, Poland, finds Jacob hiding in a peat bog. He pulls Jacob out of the mud and takes him secretly to Greece. The act of pulling Jacob out of mud is noteworthy; it is a reference to the idea that Jacob is cleared from his landscape, soil and sand. Jacob, later on, compensates for this loss in his devout relationship with place.

On the other hand, the meeting of the novel's protagonists in the bog is an overshadowing point referring to their inevitable linkage and a sincere beginning for Jacob's bond with space. The peat bog as a place witnesses Jacob's rebirth with Athos's support. The bog as a chief site is deployed by Michaels as exemplification of the buried and invisible histories and stories. The days Jacob spends as a boy in his site reflect the experiences of the prisoners at the concentration camps. Kandiyot (2004:311) suggest that Michaels may have derived this idea of bog from 
an anti-National Socialist song, 'Peat Bog Soldiers' in 1933.

Athos as a lyric geologist raises Jacob as his own son and mentee. He forms Jacob's consciousness about geology, archeology and history with his poetical elucidation about those fields. Athos's emotional relationship with place paves the way for Jacob to build up a special relationship with it. Jacob starts to believe in whatever is said by Athos about place and follows his statement, "If you know one landscape well, you will look at all other landscapes differently. And if you learn to love one place, sometimes you can also learn to love another." (Michaels, 1998:82) Adopting this theory, Jacob endeavours constantly to explore all the places he comes across with the hope of finding ways to his looted land and ways of giving meaning to it. Taking on this sensitive relationship with place, Jacob tries to mark the absence of memories.

Furthermore, Jacob's awareness of the importance of space is broadened when he is told by Athos that "We long for place; but place itself longs. Human memory is encoded in air currents and river sediment." (Michaels, 1998:53) Athos's reference to river sediments encoding memories is an indication for the idea of permanence in place. Interestingly, Simon Schama addresses the same idea in his book, Landscape and Memory. He argues in more than one way that forests, villages, mountains and rivers are with no stable reality and that it is not possible for them to be permanent. However, he refers at the same time to the poetry of the Jewish poet Adam Mickiewicz, in which Poles and Jews could find in the geography of their ruined countries what stimulated not only the memory but even dreams and fantasies. (Schama, 1996:30)

Quennet (2000:4) believes that Jacob is seen to be motivated by the same idea of permanence in space and geography; he is almost obsessed by it. As a result of this substantial concern with space, he learns how to look for memories in sediments and 'canyons', and how to read history from earth shapes. Jacob is taught by Athos that history is accumulated in layers of rocks which serve as a portrait representing human life stories and memories. Athos asserts the need of bringing these human stories to light as well. Athos and Jacob's painful memories and personal histories come to the surface through a series of expeditions guided by the former in investigating various sites like 'rock strata' and exploring the great mystery of the wood.

In depicting the relationship between memory and place in her Fugitive Pieces, Michaels is engrossed with the igmpact of this relationship. She elaborates on the nature of memory, which is crucial in providing meaning to the identity and future of Jewish people. Her elaboration is excessively expressed in her deploying of images of memories buried in different earth shapes. The use of the earth science imagery with its complex involvements is highlighted in Michaels's choice for the chapter titles of her novel: "The Drowned City, The Stone Carrier, Phosphorous". The titles, in a way, signify her absorption of the earth sciences and the working of memory. Creating a resemblance between the physical and mental world of her main characters is one of Michaels's major concerns in implementing this relationship between memories and earth science imagery. Apart from reading history from the shapes of earth and analysing the social changes of the natural world by applying the geological roles to the life of human beings, Jacob even tends to personify with places:

The landscapes of the Peloponnesus had been injured and healed so many times, sorrow darkened the sunlit ground. All sorrow feels ancient. Wars, occupations, earthquakes; fire and drought. I stood in the valleys and imagined the grief of hills. I felt my own grief expressed there. It would be almost fifty years and in another country before I would again experience this intense empathy with a landscape. (Michaels, 1998:60)

Despite the clear personification of the landscapes, this paragraph shows Jacob's emotional attitude towards places. The natural phenomenon here, landscape, is deployed to convey the horrors of the Nazi regime and the heart-breaking experience of Holocaust as being registered in space. Metaphorically, the terrible personal and collective history of Jews is grasped in Michaels's usage of earth images. Those lines uttered by Jacob raise another critical issue which is Michaels's poetic language, which expresses an intense tenderness. In narrating the violent experience of Holocaust, a brutal language is expected to express such events. However, Michaels's tender language seem to bring both the characters and readers closer of the feelings experienced in such situations. Adopting such a language, Jacob's 
horrifying experiences are transferred to the field of geology and archaeology.

By embracing a protagonist who is interested in place, Michaels derives a ground of belonging and a site of loss paradoxically from place. Belonging to place in her novel is associated with abundance respectively. In places of exile like Greece and Canada, Jacob feels a partial belonging and this can be comprehended as in a sense indicating Jacob's losses as an exilic Holocaust survivor. He lives in places which he adopts as surrogate ones to facilitate an imaginary continuation between places of his past and present. In other words, Michaels precisely introduces places from the view of the displaced which mirror the experience of Jacob as a dislocated refugee and survivor.

Conceptualizing places as vacant death sites is one of the ideas that Michaels engages with in her novel. The unavoidability of disaster is shown through a number of facts regarding the formulations of geography as death and places as void. Therefore, Jacob's experience as a survivor in those places does not show a complete sense of belonging to them. This sense of partial belonging is one of the traits of Holocaust writing adopted by Michaels. The understanding of place is accompanied by an understanding of loss for Jacob as a war survivor whose life is pictured as an epitome of the imagined lives of the Holocaust survivors. By absorbing a consciousness of the places of exile, Jacob relocates himself and reinforces a bound between these places and his own losses. The point here is that Michaels does not present places of exile as being traditionally related to alienation, terror and death. This can be regarded an invitation from her behalf to the reader to think about exilic places differently as they continuously contain and produce history and memory.

Michaels's depictions of place, on the other hand, can be considered a reaction to the Nazis' fabrication of history through manipulating places. "Nazis abused archaeology to fabricate the pas.t" (Michaels, 1998:104) This is her protagonist's, Athos's, theory in his writing about the memory of the murder of his archaeologist colleagues at Biskupin. $\mathrm{He}$ entitles his manuscript, which is mainly about the Nazification of place, 'Bearing False Witness' and it remains unfinished by the time of his death. Those places, according to the novel, are fabricated by demolishing their important landmarks. Nevertheless, Michaels insists on the point that place is a site of rebirth together with death. Hence, place is a transformative element in the novel: "Athos's backward glance gave me a backward hope. Redemption through cataclysm; what had once been transformed might be transformed again." (Michaels, 1998:101) There is an optimistic tone in Jacob's tackling of place; however, it does not mean that place is referred to as redemptive. It is more likely to be viewed as transformative. Settlement and redemption are not what Jacob finds in places while unraveling them. He, rather, as Coffey (2007:19) argues, uses them as means to give meaning to his own catastrophe.

Not every loss can be compensated in place is another notion that Michaels stresses in Jacob's preoccupation with the memory of his sister, Bella. The lack of knowledge about her destiny and inability to witness her death occupy the mind of Jacob, who attempts endlessly to seek traces of his sister's fate. The loss of Bella has more enduring consequences than the loss of his parents. His parents' death is traumatic but it is known and, therefore, can be successfully mourned. Yet, Bella's loss is attended by a sense of uncertainty and inability of mourning. This leads to Jacob's obsession with getting reports and histories about the concentration camps after the war. His lasting memory of Bella coexists with a feeling of doubt about where her life is ended. His concern about the stories of the dead victims of Auschwitz is a sign of his urgent need for tangible evidence for her death; for a site to mourn her. In parallel to Perec, it is the lack of epitaphs that leads Jacob to cling to space and to have such a strong relationship with it. Jacob depressingly confesses that his concerns about Bella are mainly because of the fact she does not have any grave.

Night after night, I endlessly follow Bella's path from the front door of my parents' house. In order to give her death a place. This becomes my task. I collect facts, trying to reconstruct events in minute detail. Because Bella might have died anywhere along the route. In the street, in the train, in the barracks. (Michaels, 1998:139)

Giving her death a place is the only way for Jacob to ease his pain and to feel that his sister rests peacefully. This is what turns his worries about Bella's death into a task. Jacob's failure in specifying the death place of Bella shows another phase of his relationship with place: devastation. A clear sense of despair can be seen in his hopeless attempts in finding about Bella's burial place. 
The narrative shifts in the second part of Fugitive Pieces as Michaels deploys another narrator, Ben, who is born after his parents are liberated from the death camps. His narration of the events turns to an elegy to Jacob, his parents and all Holocaust victims. He absorbs a history of Holocaust through the stories of his parents. He finds a photo of his parents with two children who are unknown to him; they turn out to be his siblings who were victimised in the concentration camps. This event is a turning point in Ben's life. Thus, he decides to discover more about himself by discovering others' past lives. He starts with Jacob, who was their neighbour in Canada when Ben was still a child. Ben travels to Greece, the place where Jacob lived with his wife Michaela before their death. There, he begins excavations of Jacob's house which he regards as an act with moral implications. He finds two notebooks which expose that less than a year before his death, Jacob started to write his memories. For this reason, Ben is regarded as Jacob's archaeologist, who stays at Jacob's house on the island of Idhara to reconstruct Jacob's last days. Since the house is a site of concealed and buried facts and stories of the deceased, it is more likely to be a memorial. For the same reason, Ben treats Jacob's house as museum and restores it.

"The Drowned City" is chosen as a title for the two chapters in which Ben and Jacob unfold their memories. This is significant in a way that it is a reference that there is something interlocking about the lives and the passions of the survivors. In addition to this, it is an indication that Jacob and Ben's experiences with place are similar in some aspects. Jacob encounters "wounded landscapes" and hides himself in a peat. At the same time, Ben treats wounds as landscapes and suffering as space. $\mathrm{He}$ spends his childhood in "a hiding place rotted by grief” (Michaels, 1998:233). As Jacob faces the crises of not witnessing some crucial events regarding his sister, Ben 's life is marked by an absence as well. He lives with his parents who are hiding some crucial secrets from him which may change the course of his life. He feels that he has no history and shows his interests in sites as he says

But I was born in absence. History left a space already fetid with undergrowth, worms chewing soil abandoned by routs. Rains had made the lowest pasts swampy, the green melancholia of bog with its swaying carpet of pollen. (Michales, 1998:233)
Ben digs deep in Jacob's explorations of places to realise his own losses. Ben's role as an archeologist in the novel reflects the experience of the post-war generation and it is a bridge over the gap between those who were involved in the horrendous events of Holocaust and those who survived it.

\section{CONCLUSION}

The relationship between memory and place is depicted in both Perec's $W$ or The Memory of Childhood and Michaels's Fugitive Pieces in a way that it reinforces the sensations of belonging, invitations and tranquility accompanied by sensations of alienation, rejection and despair. Jacob and Perec struggle with these sensations and endevour to transfer the alienation to belonging. At some points of their lives, they are welcomed by places and are rejected by others, at some other points. They feel tranquil in the laps of space but a feeling of dislocation is almost always unavoidable for both. Each of the two authors stresses the significance of building up this relationship for providing traces to unfold the deep buried memories.

Both Perec and Jacob admit that they do not have memories about some crucial incidents in their life. To compensate for this absence of memories, they strengthen their reliance on place. Perec originates an imaginary island to express the traumatic events of his childhood as being recorded in various places he dwells. In an attempt to uncover more details about his life, he visits a series of buildings and houses as they serve as concrete sites for holding memories and provide a feeling of safety. The lack of epitaphs is a common aspect between Jacob and Perec's quest for memories. They need a burial place for their nearest and dearest persons; a site to mourn them and overcome the grief of losing them. Interestingly, Perec deals with space in his novel in horizontal and vertical terms to represent his obsession with his mother's memory that conjuncts his life with her death. Michaels's rendering of earth science imagery is a technique to convey how memory works and how the past can be emerged to the present and future. In their par excellence method of the memory vs. place relationship, the two authors go beyond merely inscribing the everlasting scars and enduring pains of Holocaust to provide a potential of a possible healing from the traumatic memories of this genocide, embodied in place(s). 


\section{REFERENCES}

Asrtro, Alan. (1987). Allegory in Georges Perec's W ou le souvenir d'enfance. MLN 102, 867-876.

Charlesworth, Andrew, (1995). Contesting Places of Memory: The Case of Auschwitz. Environment and Planning D: Society and Space 12, 579-593.

Coffey, Dona. (2007). Blood and Soil in Anne Michaels's Fugitive Pieces: The Personal Holocaust Literature. Modern Fiction Studies 53, 13-26.

Kandiyoti, Dalia. (2004). Our Foothold in Buried World: Place in Holocaust Consciousness and Anne Michaels's Fugitive Pieces. Contemporary Literature 45, 300-330.

King, Nicola. (2000). Memory, Narrative, Identity: Remembering the Self. Edinburgh: University Press.

Kaufman, Eleanor. (1998). Falling from the Sky: Trauma in Perec's W and Caruth's Unclaimed Experiences. Diacritics 28, 44-53.
Michaels, Anne. (1998). Fugitive Pieces. London: Bloomsbury.

Nora, Pierre. (1989). Between Memory and History: Les Lieux de Mémoiré. Representations 26,725.

Pallasma, Juhani. (2009). Space, Place, Memory, and Imagination: The Temporal Dimension of Existential Space in Spatial Recall. In Marc Treib (Ed.) Memory in Architecture and Landscape (pp.4-28). London: Routledge.

Pantos, Caitlin Elizabeth. (1998). Space, Time and Georges Perec, Eternal Tableaux. Retrieved November 10, 2019, from www.pantosthemodernword.com

Perec, Georges. (2011). W or the Memory of Childhood (Trans. by David Bellos). London: Vintage Books.

-Quennet, Fabienne. (2000). Between Earth Sciences and Language/ Writing Imagery: How to Render the Working of Memory in Anne Michaels's Fugitive Pieces. COPAS 1-9.

Schama, Simon. (1996). Landscape and Memory. London:

Fontana

Press. 